\title{
Modern Approaches to Education Management to Ensure the Quality of Educational Services
}

\author{
Hassan Ali Al-Ababneh ${ }^{1}$, Salem A .S. Alrhaimi ${ }^{2}$ \\ ${ }^{1}$ Irbid National University, Irbid, Jordan \\ ${ }^{2}$ Vice president of Arab academics and scientists union, Jordan
}

\begin{abstract}
An in-depth theoretical study and a critical analysis of the main aspects and existing approaches to the definition of modern education management methods aimed at improving the quality of educational services was carried out. The necessity of using modern approaches to managing education as an integral element of the economy, which is the driver of professional growth and changes in society, is substantiated.

The features and key aspects of the formation of the institutionalization of education management in a separate university with the aim of ensuring the quality of modern education and the effectiveness of its management are considered. An in-depth analysis of the quality of educational services; a conceptualized comparison of education level indices, ratings of national education systems and their effectiveness in countries of the world. Practical recommendations have been developed on adapting the management system of educational institutions in accordance with modern economic and social requirements for the quality of educational services, which will increase audience loyalty and increase the effectiveness of management processes.
\end{abstract}

Keywords - management; education management; higher education institution; institutionalization; institutionalization of management; quality of educational services.

DOI: 10.18421/TEM92-46

https://doi.org/10.18421/TEM92-46

Corresponding author Hassan Ali Al-Ababneh, Irbid National University, Irbid, Jordan.

Email: hassan ababneh@inu.edu.jo

Received: 12 January 2020.

Revised: 04 May 2020.

Accepted: 11 May 2020.

Published: 27 May 2020.

(c) BY-NC-ND (C) 2020 Hassan Ali Al-Ababneh \& Salem A .S. Alrhaimi; published by UIKTEN. This work is licensed under the Creative Commons AttributionNonCommercial-NoDerivs 4.0 License.

The article is published with Open Access at www.temjournal.com

\section{Introduction}

The processes of globalization in the modern world are characterized by the orientation of the economic, political and cultural activities of countries towards international integration and unification - the formation of a single world community with common goals, actions and results. The quality of educational services is affected by changes in science, technology and economics.

Rather relevant in modern realities, it is the development of new educational methods and tools with the aim of improving the quality of educational services, increasing interest in studying certain scientific areas, strengthening the conditions and approaches to educational management, which in turn allows you to increase loyalty and attract more target audience. Education today also acts as the main factor in providing society with new knowledge, innovations, scientific discoveries and technologies.

The intensive development of the digital economy through the introduction of innovative tools and technologies leads to the re-profiling of specialists, which creates the demand for educational services, strengthens their role in shaping life guidelines and approaches to obtaining knowledge. It should be noted that the influence of global processes of internationalization of all sectors and activities forms the need for the interchangeability of professions and specialties that give rise to changes in both the structural and functional elements of the educational process. In this regard, quite relevant and necessary in modern conditions, is a review of existing approaches to education management in order to ensure and improve the quality of educational services, which is impossible without the implementation of innovative management methods and improvement of existing forms of management.

The issue of ensuring the quality of educational services, including by increasing the effectiveness of the education management system, is the focus of the 
work of many domestic and foreign scientists, experts in economic science and practice.

Special attention deserves a group of scientists such as: [1], [2], [3], which defines such an economic category as quality, and also addresses the main issues of management quality, including in the direction of educational services, while highlighting the role of educational services in the economic development of countries. This approach is classical in management theory and does not cover modern trends in the development of educational services, which determines the relevance and need for further research: [4], [5]. The following group of scientists made a significant contribution to the development of management theory in education: [6], [7], [8], which considers the management of the educational process through the prism of the main management functions without highlighting the key features of the organization of educational management services. This approach does not disclose all the features of educational services management: [9], [10], [11], which requires more in-depth studies in order to identify key management approaches to improve their quality. The institutionalization of education management and its features was considered by a group of the following scientists: [12], [13], which consider the main directions of education management. Particularly noteworthy are studies: [14],[15], which examine the main aspects of educational services in the world and distinguish them as the most frequently changing, which require adaptation of existing approaches to management. A significant contribution to the study of education and its development in modern conditions is given in scientific papers: [16], [17], which focus on the need for constant modernization of existing approaches to the organization of educational services.

However, it is worth noting that the definition of the main levers for improving the quality of educational services is not sufficiently disclosed and requires additional research. A significant contribution to the development of the main theoretical aspects of education management as a complex dynamic process was made by a group of the following domestic and foreign scientists, such as: [18], [19], [20], which considers the need for flexible management of educational services using standard approaches to management. The main issues of ensuring the effectiveness of the process of managing educational services using modern methods and tools are devoted to scientific works: [21], [22], which are based on the use of new interactive types of educational services. It should be noted that despite the existing developments and studies in this area, which do not allow rationally ensuring the quality and effectiveness of management, which necessitates the search for more modern approaches to education management.

Scientific developments in the field of economic theory and practice of managing educational institutions and the quality of their educational services are the basis for the development and implementation of effective measures and mechanisms to ensure the effective functioning of the education system and to increase the level of education of the population. However, it is worth noting that in view of the lack of a unified approach and the definition of a management system for educational institutions in order to ensure the quality of educational services, there is an urgent need for a detailed study within the framework of this issue, taking into account the characteristics of modern society.

The purpose of the article is to study current trends in educational services that formulate conceptual requirements for the quality of education, analyze and compare them well, identify existing barriers in the management system of educational institutions, develop practical scientific and methodological recommendations for improving the situation using modern management tools and methods.

\section{Materials and Methods}

The theoretical basis of this work was made up of key studies in the field of management and the features of its application in the management of educational services. During the study, general scientific and specific methods of cognition were used: structuring and generalization - when defining educational services as one of the most changing processes requiring new approaches and management methods aimed at improving quality; categorical analysis - in determining the categories of countries depending on national systems for ensuring the quality of education; structural analytical analysis when determining the index of the quality of educational services in the countries of the world, their effectiveness and comparison; retrospective and system analysis - in identifying key areas of educational services and identifying the main tasks to improve management efficiency and improve the quality of educational services.

In the process of the study, existing legislative and regulatory acts, decisions of legislative and executive authorities on the development of the educational services sphere, materials of websites of international organizations involved in the accreditation of universities and educational programs were used. 


\section{Results and Discussion}

Currently, the process of changing the institutional paradigm has also covered the field of education, requiring the use of new institutional functions. Education, which was based on filling an individual with formal-necessary knowledge, as noted by [1], has lost its relevance. In the context of globalization, educational institutions are also affected by the processes of internationalization, which entails structural changes at the managerial level and the need to develop new strategies for effective development.

Education forms a society by creating smart, knowledgeable and competent people who are able to develop and achieve positive results, thereby education, according to [1], provides social and economic development state. Education is defined as an important factor in the country's economic development, socio-economic progress and ensuring the sustainability of the social system. Education, as notes [2], is already being considered, not as education for the sake of education (gaining knowledge), but as a development factor that contributes to countries entering new innovative technological lines.

It is worth noting that for the modern business environment, the issue of developing the professional skills of employees and managers throughout their activities is very important, which leads to the activation of educational processes within the framework of this concept through the organization of various courses, trainings, individual lessons and areas for developing competencies. Based on this, it is necessary to state the conceptual need to review existing education management tools, namely the management of educational services, not only to complete the learning process, but to improve the quality of these services, which will increase the loyalty and interest of the audience.

Therefore, education, today, emphasize [6], is considered as a continuous process, with the possibility of receiving it throughout life and the formation of an independent educational ability in an individual. Bindé emphasizes that in the 2005 UNESCO report "To the knowledge societies", it was announced that education should be accessible throughout a person's life with a view to his personal development, ensuring the individual's ability to adapt and autonomy on a global scale.

Increased attention to the use of management tools and methods in the education system, according to [10], determines the fulfillment of the requirements and recommendations of international quality standards by the leaders of European educational institutions in the construction of education quality management systems.
The very concept of "management" is widely interpreted in world practice. Under the management is understood the way or manner of interacting with people, as well as the power and art of management, special abilities, governing body or administrative unit. However, management, as indicated by [12], is understood as art. This understanding is because organizations themselves are quite complex systems, the functioning of which depends on numerous and diverse external and internal factors.

Thus, management is an independent field of knowledge, a separate discipline, or rather an interdisciplinary field, which is most correctly called "managerial thought", combining science, experience, "know-how", augmented by managerial art. Most sciences and their achievements influence management thought. Therefore, in any field of activity, including education, one should learn to apply these achievements to obtain the desired results through the joint efforts and actions of staff.

The peculiarity of the use of management tools and methods in educational institutions, as rightly pointed out in his research [12], determine: what are the results of their work expressed in? The importance of education for the development of society and the state, the specificity of the provision of educational services in comparison with other types of services, justifies the importance of the result of the work of educational institutions, but also determines the difficulty of determining it.

In particular, the modern understanding of the activities of an educational institution is the provision of educational services, as evidenced by: the classification of the World Trade Organization, where the education sector belongs to the services sector as emphasized [23]; provisions of the World Bank [24], which considers the result of the activities of educational institutions in the form of services.

At the same time, the result of educational activity is considered specialist, in particular, a specialist - a unit of measurement of all effects, a workforce of the highest qualification, which is released to the labor market.

In addition, the activity of an educational institution is not just the production of educational services or the training of a professional specialist, but human development. Educational services mean nothing without a carrier, [10] writes, "knowledge by itself does not exist" and the professional competence of a specialist is not only knowledge possession, but also the ability to effectively apply it in practical activities.

Thus, the effective management of education should be aimed at the implementation of established goals, values and norms. Value is the proclaimed and accepted importance of education, and the goal is formed in accordance with the declared values. All 
processes are carried out in accordance with established standards.

In particular, the globalization of education provides for the adaptation of the education system to the demands of the global market economy emphasizes [24]. The modern knowledge-based economy (the "knowledge economy") provides for the creation of a single global educational space, based on uniform educational standards.

The globalization and internationalization of the education system implies the transformation of all existing processes and their flexible adaptation within the framework of the implementation of all changes dictated by the world market. It should be noted that the educational institution, according to [26],[25] is entrusted with the task of developing and integrating all the elements of the "knowledge triangle": education, research, innovation. Modern educational institutions, [27] writes, are faced with the task of both ensuring an effective educational process and developing research and innovation activities.

Hence, the quality of education is a characteristic of the educational process and the results, taking into account existing ideas about what the educational process and its results should be, as in: [28], [29]. Accordingly, the quality of education as a result is the individual's competence after the educational process, and the quality of the educational process itself is a combination of characteristics and conditions of the educational process that contribute to obtaining a high-quality educational result.

Since the result of the education is expressed by socially-determined indicators: the established level of knowledge, skills that an individual should possess after receiving educational services, then, accordingly, modern education management should be carried out in order to ensure an effective assessment of student attestation, duration of education, and satisfaction of the educational needs of the society.

Thus, the application of laws, norms, rules, management methods in relation to the field of education should be aimed at achieving a special result of educational activity that is distinct from the result of the functioning of other social and economic organizations - human development.

Education management, in this case, acts as a separate institution in the overall management system. Therefore, the management of an educational institution is an all-encompassing process aimed at:

- ensuring effective and high-quality training and education of individuals by optimizing the educational process itself and its constituent elements;
- the establishment of educational guidelines (the level of available opportunities to achieve the established goal);

- ensuring the unity of the educational process, its consideration as a system of laws, principles, contents, forms and methods;

- management of an educational organization with the involvement of all existing potential: personnel, technologies, material and technical base, information and financial resources, organizational structures, etc.

Thus, management in an educational organization is institutionalized into a system of integrated management of all educational, research, organizational activities using the existing resource base aimed at achieving a high-quality and effective result.

The institutionalization of management in education, according to [30],[31] can be explained as its organizational and legal design by creating an organizational management structure and adopting acts regulating activities. Then, the organizational management structure should be considered as a system of forms and interconnections of the organizational creation of a subsystem of an educational institution designed to manage education. The goals of such an organizational management structure should correspond to the functional goals of the international integration of education, ensuring their implementation and minimizing the negative consequences that arise.

It should be noted that the unifying tendency in the management of an educational institution, taking into account the set integration goals for the education system as a whole, is not always implemented automatically. In most cases, individual educational institutions in the event of a contradiction in their internal system of activities due to the complexity of the processes of integration and differentiation of educational activities carry it out in general.

Despite the fact that the education system has already undergone various modernizing measures, including those envisaged by the Bologna process, the planned results to ensure the quality of educational services have not yet been achieved. For example, the mobility indicators proclaimed by the Bologna process in the participating countries are growing every year, but remain low. The number of foreign students, even in leading countries, does not exceed $5 \%$ of the total number of students. The problem of "one-way mobility" remains, when the number of students arriving in the country significantly exceeds the number of students traveling abroad to study - according to The European Higher Education Area. 
The quality of education, as emphasized [32], is based on the level of satisfying consumer requirements, satisfying the needs of modern economic relations in high-quality specialists. At the same time, there is a significant gap between the triad: education, science and economics, and the inability to meet the needs of the market.

The study of the key features of higher education pays special attention to scientific works: [33], [34], [35] which consider the main stages of the process of convergence and harmonization of higher education systems in Europe to create a single European space for higher education. It should be noted that in many countries that use the Bologna process in the education system, no measures are taken to study the needs of the labor market and the direct interaction of educational institutions with potential opportunities. The main aspects of the relationship between the education system and the needs of the labor market are considered in scientific papers: [36], which highlight the main priority of this process, which is aimed at ensuring employment in the country and further employment of graduates taking into account the risks of lack of demand for "Specialists" in the market and the need for their additional training (retraining).

Based on the above, for a more detailed analysis and development of scientific and methodological approaches to the management of educational services. For clarity and the classification of countries by the level of management of educational services, this classification is divided into 3 groups:

1) high level (range of values from 0.8 to 1 );

2) average level (range of values from 0.45 to $0.79)$;

3) low level (range from 0 to 0.44 ).

We should consider the dynamics of indicators according to the rating of the countries of the world by the level of education index, which is presented in (Fig. 1.).

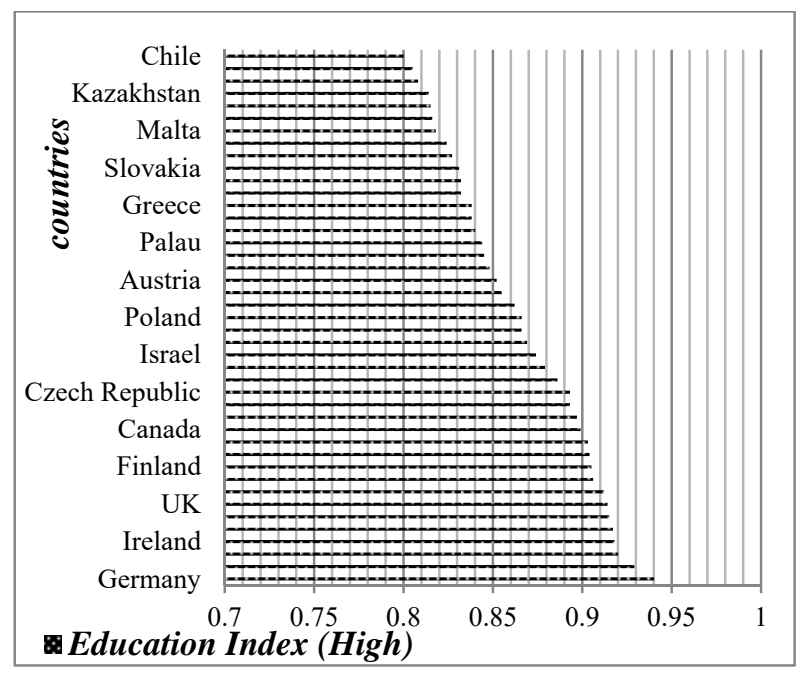

Figure 1. Dynamics of the education index with a high level in the countries of the world as of 01.01.2019
The World Education Index is a combined indicator of the United Nations Development Program (UNDP). One of the key indicators of social development. Used to calculate the Human Development Index in the framework of a special series of reports of the United Nations (UN) on human development. From the presented Figure 1. it should be noted that the highest level of education development in developed countries, the level of which ranges from 0.8 to 1 .

It is generally accepted that developed countries should have a minimum rate of 0.8 , although many of them have a score of 0.9 or higher. When determining the place in the world ranking, all countries are ranked on the basis of the Education Level Index, where the first place corresponds to the highest value of this indicator, and the last to the lowest. Literacy data comes from the official results of national population censuses and is compared with indicators calculated by the UNESCO Institute for Statistics.

For a more detailed study and analysis of the level of educational services in the world and the quality of their management, it is worth considering countries with an average level of educational services development, which are presented in (Fig. 2.).

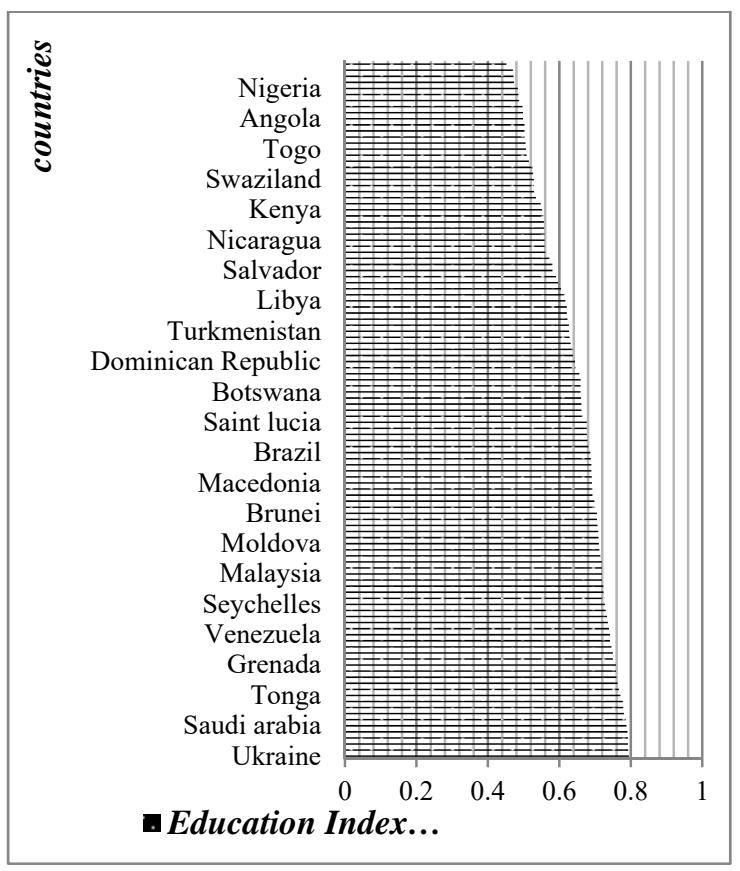

Figure 2. Dynamics of the education index with an average level in the countries of the world as of 01.01.2019

It is worth considering the rating of countries with a low level of educational services, which is presented in Fig. 3. 


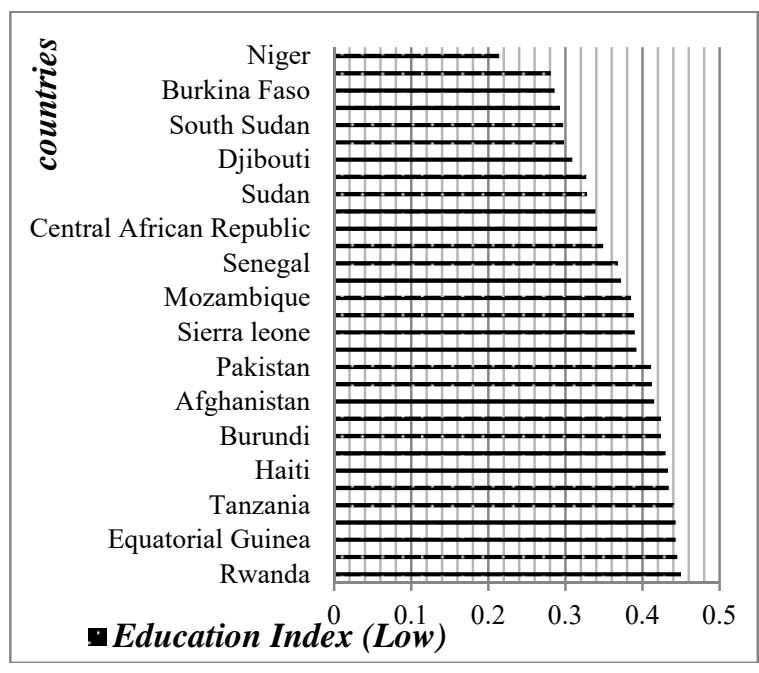

Figure 3. Dynamics of the education index with an average level in the countries of the world as of 01.01.2019

This indicator, although it is universal, has several limitations. In particular, it does not reflect the quality of education itself, which in some cases can be very low or significantly limited. Also, it does not fully show the difference in the accessibility of education due to differences in age requirements and in the duration of training. Indicators such as average duration of study or expected duration of study would be more representative; however, the corresponding data are not available in the statistics of most states. In addition, the indicator does not take into account students studying abroad, which may distort data for some small countries.

Thus, the current imbalance between supply and demand for qualified specialists, the lack of a relationship between employers and educational institutions is called important modern problems of the economy. The process of effective reform of the education system is hindered, in particular, by the use of outdated structures and methods of managing educational institutions. The need to develop and use modern management methods and carry out reforms using innovative, developing, education-based, based on modern information technologies has long been recognized [8].

The management of its educational processes also includes the management of its conditions: ensuring the professional level of the teaching staff, teaching and methodological support, material and technical, financial support of the educational process, as well as the characteristics of the student population, their potential, abilities and educational aspirations.

Moreover, the quality assurance in education, according to Memorandum of Higher Education in the European Community [37], occurs through the development of comparable criteria and methodology for assessing quality.

In particular, the main objectives of the Bologna process have been proclaimed the transparency of national education systems and their harmonization (unification), but with the preservation of the individual characteristics of education in each of the participating states, based on established recommendations and procedures.

Each participating country evaluates the programs of educational institutions based on approved accreditation systems and comparable procedures, publishes results on the quality of education of specialists, and participates in the creation of agencies designed to determine the quality of higher education.

In particular, in many European countries today there are systems of external quality assurance.

At the same time, some countries assess the quality of only individual educational programs (Czech Republic, Sweden, and Belgium), while others assess the performance of the educational institution as a whole (Great Britain, Finland). Categories of quality assurance of national education of the countries participating in the Bologna process (selectively) are presented in Table 1.

Table 1. National education quality assurance systems

\begin{tabular}{|c|c|}
\hline Category & Country Party \\
\hline $\begin{array}{c}\text { Management of national } \\
\text { quality assurance agencies }\end{array}$ & $\begin{array}{c}\text { Sweden, Finland, Russia, } \\
\text { Hungary, Ukraine, Poland }\end{array}$ \\
\hline $\begin{array}{c}\text { Conducting an external } \\
\text { assessment of the activities } \\
\text { of the national agency for } \\
\text { ensuring the quality of } \\
\text { education }\end{array}$ & Estonia, Russia \\
\hline $\begin{array}{c}\text { Conducting an external } \\
\text { evaluation of institutions or } \\
\text { programs }\end{array}$ & $\begin{array}{c}\text { Finland, Germany, Poland, } \\
\text { Hungary }\end{array}$ \\
\hline $\begin{array}{c}\text { Activities of national } \\
\text { quality assurance agencies }\end{array}$ & Poland \\
\hline $\begin{array}{c}\text { Participation in } \\
\text { international networking } \\
\text { programs }\end{array}$ & - \\
\hline
\end{tabular}

In general, most countries, when forming a system for guaranteeing the quality of education, evaluate the internal system of educational process management. At the same time, despite the fact that in almost all countries of the Bologna process educational institutions are required to form an internal quality assurance system, an external quality assurance system continues to have a significant impact on it. Hence, the main debate arises that the modernization of national education should take into account the national mentality, culture and market needs, primarily the national The European Higher Education Area [36].

Modernization should be directed to those areas in which it is necessary to increase efficiency, taking into account all possible consequences and with a 
clear understanding of the goals to which it is aimed, and not comprehensively to the entire education system only for the sake of changes and transformations. This also applies to the sphere of education management in general, and the educational institution in particular.

Given the foregoing, the main task in the construction and functioning of the educational institutions management system is to find the optimal balance in opposing trends, minimize contradictions and organizational conflicts. The institutionalization of education management can be effective only if it is supplemented by measures of an economic, informational and analytical nature. For all the existing factors, both contributing to the institutionalization of education management, as well as hindering it, the processes of globalization and integration, the socio-economic state of the country, the conditions and priorities of the ultimate goal of the educational process, require the establishment of education management in a higher educational institution in individual institutions, which are organizational -legal management structure in the educational sphere. Based on the above, it is worth considering the gradation of countries according to the index of effectiveness of national education systems as of 01.01.2019, which is presented in (Fig. 4.).

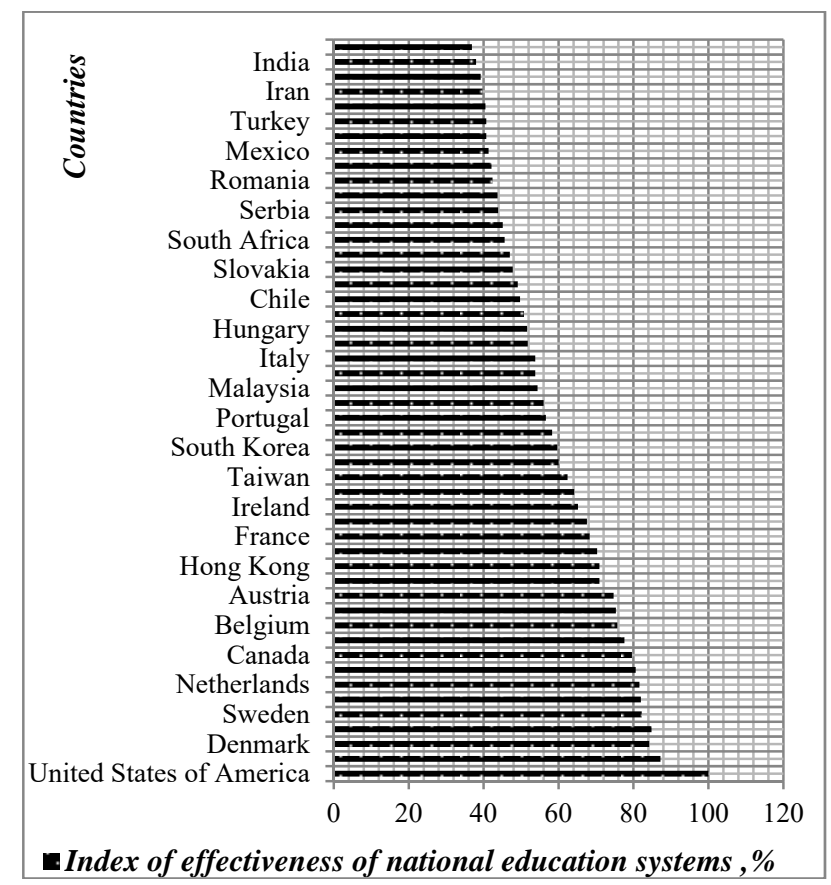

Figure 4.. Graduation of countries by the index of effectiveness of national education systems as of 01.01.2019

The index of the effectiveness of national education systems (Global Index of Cognitive Skills and Educational Attainment) is a global study and its accompanying rating, which measures the achievements of the countries of the world in the field of education. It is produced by the British international company Pearson, which specializes in educational and publishing activities.

The rating is calculated according to the methodology of The Economist Intelligence Unit research company and estimates the level of effectiveness of education systems in the countries of the world.

Therefore, to ensure the effectiveness of education management, it is necessary to:

- pay attention to creating an effective organizational and methodological model of training, retraining, improving knowledge and experience of the personnel of the educational institutions;

- take into account the needs of the labor market for qualified professionals;

- promote self-realization, growth of scientists, their realization of their potential, provide them with moral and material support.

In other words, modern education management should be carried out in the direction of:

- improving the quality of education and ensuring its accessibility;

- ensuring continuing professional education;

- improving the financing system;

- orientation to the needs of the labor market and economic priorities;

- the union of science and education: not only the use of modern innovations in education, but also contributing to the creation of innovations and their introduction into the economy.

Separately, it should be pointed out that the effectiveness of managing an educational institution also depends on external factors that arise when managing the education system in the country as a whole.

Such factors are, in particular, inadequate resource support of state-financed educational institutions, economic crises, the country's backlog in integration processes, low level of material support for citizens, lack of an effective regulatory and methodological base for education management, etc.

Internationalization, as noted by Wood [36], poses new institutional challenges for educational institutions: ensuring the mobility of academic staff and students, meeting the educational institution's international standards, and conducting quality control of educational activities. In other words, the impact on the education sector of globalization trends requires the heads of educational institutions to possess new means, methods and methods of organizing, managing and controlling research and educational activities, that is, applying the 
knowledge, rules and laws of modern management in education aimed:

- to change the management of material, technical, academic, financial resources;

- to improve the quality of education in accordance with both national and international evaluation criteria;

- on the training and retraining of faculty and ensuring the flexibility of the learning process aimed at individual freedom in the choice of areas of study and the formation of their professional competence.

\section{Conclusion}

Modern education management should focus on the constant adaptation of the educational institution to the conditions of a dynamically changing economic and social environment. Effective management of an educational institution should be aimed at ensuring the quality of the educational process and the result that meets the needs of participants in the educational process and society.

The education system must adapt to the demands of the global market economy. And the management system of the educational institution should ensure effective changes in the educational process. Modernization of the education system should be directed to those areas in which changes are necessary to increase efficiency, taking into account all possible consequences.

The main problems today are the timely identification of labor market needs for the formation of the necessary training programs, the mastery of educational institutions by innovative methods and management tools to eliminate obsolete inefficient structures, etc. Overcoming problems in the education system helps to improve the quality of education, both of a single institution, and national, and in turn global.

A single model of the education quality management system does not exist today, therefore, despite the fact that the effectiveness of managing an educational institution depends on external factors that arise when managing the education system in the country as a whole, the main responsibility for the effectiveness of the educational process and the quality of the educational services provided is assigned to managerial staff of an educational institution and is based on the development and use of modern management methods, innovative methods second, developing, based on modern information technologies and education.

\section{References}

[1]. Cicmil, S., Gough, G., \& Hills, S. (2017). Insights into responsible education for sustainable development: The case of UWE, Bristol. The International Journal of Management Education, 15(2), 293-305.

[2]. Martincic, R. (2010). Change management in adult educational organizations: A Slovenian case study. Managing Global Transitions, 8(1), 79-96.

[3]. Brighem, Y. J. (2005). Finansovyj menedzhment. Ekonomicheskaya shkola, 1(25), 1110-1166.

[4]. Chandler, A. D. (1990). Strategy and structure: Chapters in the history of the industrial enterprise (Vol. 120). MIT press.

[5]. Porter, M. E. (1980). Competitive Strategy The Free Press: New York. PorterCompetitive Strategy1980, 324-425.

[6]. Oplatka I. D., \& Hemsley-Brown J. (2012). Advances in Educational Administration, The Management and Leadership of Educational Marketing, 15, 325-368.

[7]. Birnbaum, R., \& Snowdon, K. (2003). Management fads in higher education. The Canadian Journal of Higher Education, 33(2), 122.

[8]. Grace, G. R., \& Grace, G. (1995). School leadership: Beyond education management: An essay in policy scholarship. Psychology Press.

[9]. Spence, C. (2019). 'Judgement'versus 'metrics' in higher education management. Higher Education, 77(5), 761-775.

[10]. Saunders, A., \& Schumacher, L. (2000). The determinants of bank interest rate margins: an international study. Journal of international Money and Finance, 19(6), 813-832.

[11]. Drucker P.F. (1999) Management Challenges for the 21st Century. Harper Business. 135.

[12]. Scaglione, V. L. T., Meyer, V., \& Mamédio, D. F. (2019). Improvisation in higher education management: Coping with complexity and organizational dynamics. Global Journal of Flexible Systems Management, 20(4), 291-302.

[13]. Tompson A. A. (2006) Strategicheskij menedzhment: koncepcii i situaciidlyaanaliza. 928.

[14]. Adamchuk, D., Beshenkov, S., \& Mindzaeva, E. (2019, May). Sociology of Education: Prerequisites for Modernizing the Food Management System at Schools. In International Conference on the Development of Education in Eurasia (ICDEE 2019). Atlantis Press.

[15]. Zeer E. F. (2000). Psihologiya lichnostnoorientirovannogo professionalnogo obrazovaniya. 258.

[16]. Symanyuk E. E. (2001). Osnovy lichnostnoorientirovannogo obrazovaniya. 51.

[17]. Burke-Smalley, L. A., Rau, B. L., Neely, A. R., \& Evans, W. R. (2017). Factors perpetuating the research-teaching gap in management: A review and propositions. The International Journal of Management Education, 15(3), 501-512.

[18]. Davis, C. H., \& Comeau, J. (2020). Enterprise integration in business education: Design and outcomes of a capstone ERP-based undergraduate ebusiness management course. Journal of Information Systems Education, 15(3), 8. 
[19]. Allen, S., Cunliffe, A. L., \& Easterby-Smith, M. (2019). Understanding sustainability through the lens of ecocentric radical-reflexivity: Implications for management education. Journal of Business Ethics, 154(3), 781-795.

[20]. World Trade Organization (2001): Documents and Comments. Moscow: Chamber of Commerce and Industry of the Russian Federation. 325

[21]. Constructing Knowledge Societies (2003): New Challenges for Tertiary Education The World Bank Washington. 232.

[22]. Coleman M. J., \& Glover C. D. (2010). Educational Leadership And Management. 125-368.

[23]. Adamkulova C. U. (2016). Modernization of Higher educational in Kyrgyzstan in the Conditional Internalization. European journal of economics and management sciences. 5, 30-34

[24]. O'Leary, D., \& Oakley, K. (2008). The skills paradox: confronting inequality in adult learning. 256.

[25]. Faubert, B. C. (2019). Transparent Resource Management: Implications for Leadership and Democracy in Education. International Journal of Educational Management, 33(5), 965-978.

[26]. Haertle, J., Parkes, C., Murray, A., \& Hayes, R. (2017). PRME: Building a global movement on responsible management education. The International Journal of Management Education, 15(2), 66-72.

[27]. Bess J.D, \& Dee J.S. (2012). Understanding College and University Organization. 125

[28]. Shimko, P. D. (2008). Management of processes of globalization of higher education at institutional and regional levels. Bulletin ENGECON.«Economy» series, (3), 22.
[29]. Motova, G. N. (2016). The Bologna Process: 15 Years Later. Russian Education \& Society, 58(4), 313-333.

[30]. Shams, S. R., \& Belyaeva, Z. (2019). Quality assurance driving factors as antecedents of knowledge management: A stakeholder-focussed perspective in higher education. Journal of the Knowledge Economy, 10(2), 423-436.

[31]. Almeida, J., Daniel, A. D., \& Figueiredo, C. (2019). The future of management education: The role of entrepreneurship education and junior enterprises. The International Journal of Management Education, 100318.

[32]. De Wit H. (2020). Internationalization of higher education. Journal of International Students. 10(1), 150.

[33]. Byram, M., Hu, A., \& Rahman, M. (2019). Are researchers in Europe European researchers? A study of doctoral researchers at the University of Luxembourg. Studies in Higher Education, 44(3), 486-498.

[34]. Gutierrez, A. P., Fortmann, A. L., Savin, K., Clark, T. L., \& Gallo, L. C. (2019). Effectiveness of diabetes self-management education programs for US Latinos at improving emotional distress: a systematic review. The Diabetes Educator, 45(1), 13-33.

[35]. Heinicke, X., \& Guenther, T. W. (2019). The Role of Management Controls in the Higher Education Sector: An Investigation of Different Perceptions. European Accounting Review, 1-50.

[36]. Wood, P. (2017). Overcoming the problem of embedding change in educational organizations: A perspective from Normalization Process Theory. Management in Education, 31(1), 33-38. 